\title{
Banning ritual circumcision of children in Iceland
}

Arndís A. K. Gunnarsdóttir

\section{OpenEdition}

\section{Journals}

Electronic version

URL: http://journals.openedition.org/rdr/342

DOI: $10.4000 /$ rdr.342

ISSN: 2534-7462

\section{Publisher}

Presses universitaires de Strasbourg

\section{Printed version}

Date of publication: 6 November 2018

Number of pages: 161-171

ISBN: 979-10-344-0023-2

ISSN: 2493-8637

\section{Electronic reference}

Arndís A. K. Gunnarsdóttir, «Banning ritual circumcision of children in Iceland », Revue du droit des religions [Online], 6 | 2018, Online since 25 November 2019, connection on 20 November 2020. URL http://journals.openedition.org/rdr/342 ; DOI : https://doi.org/10.4000/rdr.342

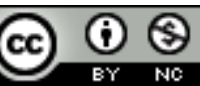

La revue du droit des religions est mise à disposition selon les termes de la Creative Commons Attribution - Pas d'Utilisation Commerciale 4.0 International - CC BY-NC 4.0. 


\section{BANNING RITUALCIRCUMCISION OFCHILDREN INICELAND}

\section{Amdís A. K. GUNNARSDÓTTIR}

Doctorante en droit publicde l'Université de Strasbourg

celand, a small island nation in the North Atlantic Ocean, known for its
respect for human rights and natural contrasts of fire and ice, a democratic republic built on the Nordic model in economic and social policies, made it into the world news in 2009 with its financial crisis and kitchenware revolution, and again in 2010 with the Eyjafjallajökull eruption which caused major disruptions of air traffic in Europe. Once again, Iceland has unexpectedly drawn worldwide attention, this time with a proposal for a change in the country's General Penal Code, criminalizing the non-medical circumcision of male children.

This paper provides a short background of the proposal, followed by an overview of the current legal situation. The bill - which merely suggests the omission of the words "girl" and "her" in the current provision in the Penal Code on female genital mutilation (FGM or female circumcision) - is still under discussion in the Parliament. Were the bill to be passed, Iceland would be the first European country to explicitly ban the ritual circumcision of children. 


\section{THE BACKGROUND OF THE PROPOSAL}

\subsection{TIMING OF THE PROPOSAL}

Circumcision of children is not and never has been a widespread tradition in Iceland. ${ }^{1}$ There are very limited sources on the practice of male circumcision in Iceland, and only slightly more on FGM. This is unsurprising, given that circumcision is not, and has never been, a common practice in Iceland. Female genital mutilation was penalized in Iceland in 2005, with an amendment to the General Penal Code No. 19/1940. The commentary to the original proposal ${ }^{2}$ referred to increasing immigration as one of the reasons for it, with the ban being seen as preemptive while the act of female circumcision was still close to unknown in Iceland, and to the role of Iceland in fighting against FGM in the global context. ${ }^{3}$

The reasons for the timing of the 2018 proposal for a ban of ritual male circumcision are less clear. The commentary to the proposal itself starts by explaining that in recent years the opinion has become more widespread that circumcision without a medical necessity entails a violation of the human rights of boys, as it is an irreversible interference in their body without them having a say in the decisions, and that it is a painful and risky procedure. The bill is seen by the authors as a second step in the process started with banning female circumcision, to also ban the genital mutilation [sic] of boys. ${ }^{4}$

In its annual report for 2011, in response to a communication received by the office, the Icelandic Children's Ombudsman called for a change in the law to articulate a clear ban on circumcision of boys without the recommendation of a doctor. The Ombudsman mentioned that such a ban existed for girls, but not for boys, and stated that boys' circumcision is unusual in Iceland but that it is not entirely clear in the law whether or not parents can decide to have their child circumcised for non-medical reasons. Reiterating that children enjoy fundamental rights like adults, and pointing out that a circumcision

1. According to information from the Directorate of Health from 2016, responding to a request from the Parliament, only one circumcision was performed at the Children's hospital since 2013, which only performs such operations for medical reasons. One was registered in 2009 and one in 2012: http://www.althingi.is/altext/145/s/1126.html [accessed 12 June 2018].

2. The ban was originally proposed in 2003 , as a bill for a separate legislative act.

3. See the original proposal with commentary on the website of Alpingi, the Icelandic Parliament: http://www.althingi.is/altext/128/s/1155.html [accessed 12 June 2018].

4. See the bill and comments on the website of the Parliament: http://www.althingi.is/ altext/148/s/0183.html [accessed 12 June 2018]. 
can be both painful and entail risks of infection and other complications, it is considered questionable to allow parents to change a child's body without medical necessity. The Ombudsman, furthermore, suggested a minimum age of 16 for a child to approve circumcision, as at that age children are generally considered to have the right to make decisions e.g. about medical treatment and membership in religious communities. ${ }^{5}$

In 2013, the children's ombudsmen of the six Nordic countries, along with doctors and pediatricians, signed a declaration regarding the non-medical circumcision of newborn males claiming that it violates fundamental medicalethical principles. ${ }^{6}$ Nothing seems to suggest any particular case or incident prompted the 2018 proposal.

\subsection{PUBLIC DEBATE}

The bill caught the attention of the press in Iceland as soon as it was put forth in the Parliament at the end of January 2018 by nine members of Parliament from four different political parties, ${ }^{7}$ and immediately sparked intense public debate. To the surprise of some, the bill also quickly gained international attention. Representatives of Jewish communities in Europe campaigned against the bill, ${ }^{8}$ and religious leaders in Iceland, as well as abroad, spoke out in the media, claiming the bill posed a threat to freedom of religion in Iceland.

The director of the Islamic Foundation in Iceland claimed in an interview that circumcision is a Muslim right, and that it is indispensable. He warned that with a ban people would start performing circumcisions themselves, without medical supervision, emphasizing that male circumcision is performed all around the world and cannot be compared with FGM. ${ }^{9}$ The president of the Catholic Church in the European Union (COMECE) expressed his

5. "Skýrsla umboðsmanns barna 2011", available on the website of the Ombudsman: https:// www.barn.is [accessed 12 June 2018].

6. See the complete declaration as published on the website of Child Rights International Network (CRIN): https://www.crin.org/en/docs/English-statement-.pdf [accessed 12 June 2018].

7. The Left-Green Movement, the People's Party, the Pirate Party and the Progressive Party. See further information in English on the website of Alpingi, the Icelandic Parliament: http:// www.althingi.is/english/members-of-parliament/political-parties/ [accessed 12 June 2018].

8. K. NACHSHONI, "Iceland set to ban circumcision", Ynetnews, 2 January 2018: https://www. ynetnews.com/articles/0,7340,L-5079596,00.html [accessed 12 June 2018].

9. "Með og á móti - Umskurður drengja", 11 February 2018: http://www.dv.is/fokus/ folk/2018/02/11/med-og-a-moti-umskurdur-drengja/ [accessed 12 June 2018]. 
concern about the bill claiming that it's "a dangerous attack on freedom of religion". ${ }^{10}$

During the first round of discussions in the Parliament, the standing committee on Judicial Affairs and Education received around 100 comments on the proposal, from individuals, institutions and associations, religious societies, healthcare and other professionals, from within Iceland and abroad, both for and against the bill. ${ }^{11}$

The European Jewish Congress opposed to the equation of male circumcision with FGM and emphasized the importance of the timing of circumcision in Judaism. ${ }^{12}$ The Islamic Cultural Center also criticized the comparison with FGM - citing possible health benefits of male circumcision as compared with FGM which serves the only purpose of reducing a woman's life satisfaction - and explaining the prevalence and importance of circumcision of boys at a young age in Islam. The cultural center also pointed out the low prevalence of circumcision of children and hence the lack of any pressing need to criminalize it. ${ }^{13}$

Even many Christian associations and sects opposed the bill with reference to freedom of religion of the parents, and their right to bring up their children in line with their faith. The Evangelical Pentecostal Church emphasized the right of parents to decide what is best for their children, mentioning vaccinations as another example, and called attention to the question of whether making circumcision subject to punishment would in reality protect children, naming the consequences of illegal abortion as an example, i.e. the risk of people resorting to unsafe and illegal ways of performing the act. Without doubting the good intention of the authors of the bill, the Evangelical Church brings up the controversy of welcoming refugees to

10. "COMECE President expresses deep concern about criminalisation of circumcision", 6 February 2018: http://www.comece.eu/comece-president-expresses-deep-concern-aboutcriminalisation-of-circumcision [accessed 12 June 2018].

11. After the first round of discussions (out of three) in the Parliament, a bill is generally passed over to a standing committee, to examine the bill in more detail. Anyone is allowed to submit comments on a bill, which will be examined by the standing committee before deciding on whether to forward the bill (with or without suggestions for amendments) to a second round of discussions in the Parliament or not. See the complete list of submissions to the circumcision bill on the website of the Icelandic Parliament: http:// www.althingi.is/thingstorf/thingmalin/erindi/?ltg=148\&mnr=114 [accessed 12 June 2018].

12. The European Jewish Congress's comment on the proposal, 27 March 2018: http://www. althingi.is/altext/erindi/148/148-1008.pdf [accessed 12 June 2018].

13. The Islamic Cultural Center of Iceland comments on the proposal, 20 March 2018: http:// www.althingi.is/altext/erindi/148/148-984.pdf [accessed 12 June 2018]. 
Iceland and at the same time criminalizing an important factor of many refugees' religion, and objects to the bill declaring the same good intention towards children of immigrants and all Muslim and Jewish children. ${ }^{14}$ The Bishop's Office formally opposed the bill pointing out the risk of Judaism and Islam being effectively outlawed from Iceland and that such extremes should be avoided, and stating that the question at hand is about the balance between the rights of the child to bodily integrity as weighed against the right of the child to be raised in line with religious and cultural traditions of its family, which can form their identity. ${ }^{15}$

The opposing side reacted to the criticism, and close to two thousand Icelandic doctors and nurses signed a declaration supporting the bill. ${ }^{16}$ The Icelandic medical journal also took a stand supporting the bill. ${ }^{17}$ Adult circumcised individuals stepped forward voicing their support for the ban, referencing their own personal experiences, ${ }^{18}$ and over one thousand Danish doctors declared support for the bill. ${ }^{19}$

Opinions in the Parliament seem individual and not split along party lines. The proposal, as written, received some criticism from those who approve of the intention but doubt the method (i.e., adding a provision to the Penal Code, which would equate male circumcision and FGM, where an age limit for circumcision in the Act on the Rights of Patients would be more effective and appropriate). The arguments for either an age limit or a total ban on circumcision are consistent: the rights of children to bodily integrity, not having to endure unnecessary risk or suffering, and freedom of religion of the child. ${ }^{20}$

14. The comments of Filadelfia, the Evangelical Pentecostal Church in Iceland: http://www. althingi.is/altext/erindi/148/148-1015.pdf [accessed 12 June 2018].

15. The Bishop's Office's comment on the proposal, 17 February 2018: http://www.althingi. is/altext/erindi/148/148-306.pdf [accessed 12 June 2018].

16. "Á fimmta hundrað íslenskra lækna fagna umskurðarfrumvarpi": http://www.visir. is/g/2018180229765/a-fimmta-hundrad-islenskra-laekna-fagna-umskurdarfrumvarpi, 21 February 2018, and a declaration available on the website of the Alpingi: http://www. althingi.is/altext/erindi/148/148-489.pdf [accessed 12 June 2018].

17. See the website of the journal: http://www.laeknabladid.is/tolublod/2018/03 [accessed 12 June 2018].

18. See on the website of Alpingi: http://www.althingi.is/altext/erindi/148/148-714.pdf and "Hrafn er umskorinn og hefur liðið sálarkvalir vegna pess": http://www.visir. is/g/2018180229798, 21 February 2018 [accessed 12 June 2018].

19. See on the website of Alpingi: http://www.althingi.is/altext/erindi/148/148-825.pdf [accessed 12 June 2018].

20. The related issue of the rights of intersex children to bodily integrity was mentioned during the parliamentary debate as well, pointing out the possibility of combining the two in a provision in the Act on the Rights of Patients. 


\subsection{RELIGION AND RELIGIOUS FREEDOM IN ICELAND}

To assess the possible impact of the law at the national level, some basic demographics and jurisprudence may be interesting. Despite the high percentage of Icelanders who identify as Christian (68.8\%), only $46 \%$ consider themselves religious, and the vast majority of the population acknowledges the Big Bang as the precipitating event leading to the formation of Earth. Only about $18 \%$ believe the world was created by a god. ${ }^{21}$

According to Article 62 of the Constitution, the Evangelical Lutheran Church is the National Church of Iceland and the state is to protect and support it as such. On 1 January 2017 the Church had 236,481 members, or around $70 \%$ of the population. ${ }^{22}$ Three Muslim religious societies were registered with a total number of 948 members on that same date. There is no registered Jewish religious society in Iceland ${ }^{23}$ and there are no official figures on the number of Jews in Iceland, but the media has estimated 50-100 practicing Jews. ${ }^{24}$

Freedom of religion is guaranteed in Article 63 of the Constitution, which states, "All persons have the right to form religious associations and to practice their religion in conformity with their individual convictions. Nothing may, however, be preached or practiced which is prejudicial to good morals or public order." Iceland is party to the Council of Europe, and has both ratified the European Convention of Human Rights and incorporated it in its entirety into national legislation. ${ }^{25}$ Article 1 of the Act on Registered Religious Associations No. 108/1999 reiterates the provision in Article 63 of the Constitution, adding that it is not obligatory to report the establishment and operation of a religious society to the authorities.

21. According to a survey done for the Icelandic Ethical Humanist Association in 2015: http://sidmennt.is/wp-content/uploads/L\%C3\%ADfssko\%C3\%B0anir-\%C3\%8DslendingaSi\%C3\%B0mennt.pdf [accessed 12 June 2018].

22. A drop from $81 \%$ in 2007 , see the database of Statistics Iceland, at www.hagstofa.is. A newborn child is registered in the same religious society as the parents if they have the same registration.

23. Ibid.

24. "Lítið en líflegt samfélag gyðinga á Íslandi": http://www.visir.is/g/2013130809680, and "Iceland's Handful of Jews Keep Faith Alive", 4 August 2013: https://forward.com/ news/181557/icelands-handful-of-jews-keep-faith-alive/ [accessed 12 June 2018].

25. See Act No. 62/1994 on the European Convention of Human Rights. 
Only three cases on freedom of religion have been adjudicated since the turn of the century. ${ }^{26}$ Before that such cases were almost unheard of and then only in the context of defamation and blasphemy. ${ }^{27}$ In 2007, one important case regarding Articles 62 and 65 of the Constitution (non-discrimination and equality), involved tax revenues awarded to the National Church. ${ }^{28}$ In 2010, a claim for the annulment of the covenant of baptism was dismissed by the court on the grounds that the plaintiff had no legitimate interests in a ruling on the issue. ${ }^{29}$ In a case from 2016, the defendant based his defense on freedom of religion but the case was decided on freedom of expression and labor law. ${ }^{30}$

\section{THE CURRENT LEGAL SITUATION IN ICELAND}

\subsection{GENERAL PENAL CODE N0. $19 / 1940$}

After the 2005 amendment banning female circumcision, Article 218a of the General Penal Code states:

"Any person who, in an assault, causes physical injury or damage to the health of a girl child or woman by removing her sexual organs, partly or in their entirety, shall be imprisoned for up to 6 years. If the assault results in serious physical injury or health damage, or in death, or if it is considered particularly reprehensible due to the method used, punishment for the offense shall take the form of up to 16 years' imprisonment."

In the public debate surrounding this amendment, some questioned whether the act of FGM needed a specific penalization beyond the existing provisions in the General Penal Code on assault. According to Article 217 of the General Penal Code:

"Any person convicted of assault, providing it is not as serious as is described in Article 218, shall be fined or imprisoned for up to 6 months, and imprisoned for up to 1 year if the conduct involved is particularly reprehensible.

26. R. HelgadóttiR, "Hugsana-, samvisku- og trúfrelsi" [Freedom of thought, conscience and religion], in B. THORARENSEN (ed.), Mannréttindasáttmáli Evrópu: meginreglur, framkvacmo og áhrif á íslenskan rétt [The European Convention on Human Rights: principles, application and effect on Icelandic law], Reykjavík, Bókaútgáfan Codex, 2017, p. 349.

27. Supreme Court Judgments of 1992, p. 401 and of 1984, p. 855.

28. Supreme Court, 25 Oct. 2007, No. 109/2007, Ásatrúarfélagið v. Iceland.

29. Supreme Court, 8 Nov. 2010, No. 262/2010, A and B v. the National Church and C.

30. Supreme Court, 11 Febr. 2016, No. 396/2015, Akureyrarkaupstaður v. Snorri Óskarsson. 
The prosecution authorities shall bring court actions arising from offenses under the first paragraph, and this shall not be done unless demanded by the public interest."

Article 218 of the same act states:

"If by a deliberate assault someone causes another person physical injury or health damage and these consequences can be regarded as his or her fault in terms of intention or negligence, the person shall be imprisoned for up to 3 years, or fined if there are extenuating circumstances.

Where serious physical injury or health damage results from an assault or where the offense is particularly dangerous in view of the method, including the implements, used, and also where the assault victim dies as a consequence of the attack, punishment for the offense shall take the form of up to 16 years' imprisonment."

The same argument has been made in the debate about the newly proposed ban. For example, a former Supreme Court justice officially claimed a separate provision prohibiting circumcision of children is unnecessary, as they are already protected against circumcision by provisions in the General Penal Code on assault. ${ }^{31}$

\subsection{LAWS ON THE RIGHTS OF CHILDREN AND DUTIES OF PARENTS}

The Convention on the Rights of the Child (CRC) was incorporated into national law in its entirety in 2013. Furthermore, the basic principle derived from Article 3 of the CRC - that in all actions concerning children the best interests of the child shall be a primary consideration - is reiterated in various national legislative acts. Article 14 of the CRC covers the freedom of religion of the child, as well as the rights and duties of the parents to provide direction to the child in the exercise of his or her right in a manner consistent with the evolving capacities of the child.

General provisions on parental duties and the meaning of custody are found in Article 28 of the Children Act No. 76/2003, which states, i.a., that parents are obliged to look after their children and show them care and respect, and to discharge their duties of custody and upbringing in the way that best suits the children's interests and needs. Custody of a child includes the duty of the parents to protect the child against violence of all types and other degrading conduct. Furthermore, custody of a child includes the right and obligation to take decisions regarding the child's personal circumstances

31. J. S. Gunnlaugsson, "Nú pykir mér tíra!", 26 February 2018: http://eyjan.dv.is/ eyjan/2018/02/26/nu-thykir-mer-tira/ [accessed 12 June 2018]. 
and to determine the child's place of residence. Finally, parents have an obligation to consult their child, according to the child's age and level of maturity, before taking a final decision on the child's affairs.

Article 1 of the Child Protection Act No. 80/2002 also deals with the duties of parents, stating, that "children have a right to protection and care and that their rights shall be maintained in accordance with their age and maturity". The second paragraph emphasizes that "all those involved in the care and upbringing of children shall treat them with respect and consideration, and no child may ever be subjected to violence or any other degrading treatment". Although general in wording, these provisions have been suggested as a legal foundation against infant circumcision.

Despite the clear rights and duties of parents to make decisions on behalf of their children, it seems clear that under no circumstances can parents agree to their children being subject to violence. Physical punishment, in any form, is e.g. explicitly prohibited and subject to fines or up to three years' imprisonment, according to Article 99 of the Child Protection Act.

\subsection{ACT ON THE RIGHTS OF PATIENTS N0. 74/1997}

Some have argued that circumcision of infant children is already prohibited according to Article 27(2) of Act on the Rights of Patients, No. 74/1997. The relevant provision merely states that children shall be spared unnecessary tests and procedures. Article 7(1) states that a patient has the right to decide whether they receive medical treatment. For people who are unable to make such a decision themselves, e.g., because of age, the provisions of the Act on Legal Competence, No. 71/1997 apply regarding the authority of a legal guardian. Nevertheless, a patient should be consulted to the extent possible (Art. 7(2) of the Act on the Rights of Patients).

Pursuant to Article 26, the legal guardians of a minor child must give consent for the necessary treatment of a child younger than 16 years old. A child should be consulted when possible, and children 12 and older should always be consulted. If the parents or legal guardians of a child refuse to give their consent to a necessary treatment, a doctor or another health professional shall turn to the child protection authorities, (Child Protection Act No. 80/2002). ${ }^{32}$ If there is no time to seek the support of the child

32. According to Article 29(1)(b) of the Act, a child protection committee may take court action for a parent or parents to be deprived of custody if the committee believes that an ill child or child with disability is not ensured suitable treatment, therapy or teaching. 
protection authorities for a vital emergency treatment, medical staff is obliged to consider the child's health as the guiding principle and take immediate action for the necessary treatment.

\section{THE PROPOSED BAN ON MALE CIRCUMCISION}

The legislative proposal is short and simple, and merely suggests that the text of Article 218a of the General Penal Code be amended by eliminating the words "girl" and "her" in the first sentence of the first paragraph. The article would then be as follows:

"Any person who, in an assault, causes physical injury or damage to the health of a girl child or woman by removing her sexual organs, partly or in their entirety, shall be imprisoned for up to 6 years. If the assault results in serious physical injury or health damage, or in death, or if it is considered particularly reprehensible due to the method used, punishment for the offense shall take the form of up to 16 years' imprisonment."

Despite the fact that the perpetrator according to the article would be the person performing the act, criminal responsibility of the parents of the child might be invoked by Article 22(1) of the General Penal Code, which states that "any person who, by assisting in word or deed, through persuasion, encouragement or in any other manner, contributes to the commission of an offense under this Act shall incur the punishment prescribed for the offense".

According to Article 218b of the Code, the punishment that would otherwise apply may be reduced where consent is given for an assault. Whether parents can give consent to physical assault on behalf of their children has not been dealt with by Icelandic courts, but in light of the aforementioned provisions of the Children Act and the Child Protection Act, this should be considered very unlikely.

\section{CONCLUSION}

Awareness of and respect for children's rights has been increasing over the past decades, with the adoption of the UN Declaration on the Rights of the Child in 1959, leading to the Convention on the Rights of the Child in 1989, with further advancements of particular children's rights via additional protocols in 2000 and 2011. At the same time, the debate over whether 
allowing infant circumcision is consistent with children's basic rights is increasing, with calls to abandon the tradition coming from individuals and professionals. Given the low number of male circumcisions already performed in Iceland, it is unlikely to have a major impact in the national context. Perhaps for this reason, Iceland may be in an ideal position to set an example, as the first European country to explicitly ban the ritual circumcision of children. Only hindsight, however, will elucidate the proposal's historical importance in the global context. 